\title{
ANALISIS KEKUATAN VELG ALUMINIUM ALLOY 17 INC DARI BERBAGAI DESAIN MENGGUNAKAN METODE FINITE ELEMENT ANALYSIS (FEA).
}

\author{
Fahd Riyal Pris ${ }^{1}$, Budhi M Suyitno ${ }^{1}$, Amin Suhadi $^{1}$
}

${ }^{1}$ Departemen Teknik Mesin, Fakultas Teknik, Universitas Pancasila, Srengseng Sawah Jagakarsa, DKI Jakarta, 12640, Indonesia

\begin{abstract}
ABSTRAK
Pelek adalah bagian unit kendaraan yang berfungsi sebagai penahan/penopang beban kendaraan pada saat keadaan diam, serta sebagai penerus gerak putar dari mesin untuk memindahkan kendaraan dari satu tempat kepada tempat yang lain. Pelek kendaraan ini adalah untuk kendaraan roda 4 dengan bahan baku utama adalah aluminium serta dipadukan dengan bahan lain (alloy) dengan paduan aluminium alloy 1060.

Pada pelek ini melalui beberapa tahapan proses pengujian untuk mengetahui kekuatan pada saat static dan dinamik. Adapun proses analisa yang dilakukan dengan metode perhitungan yang disesuaikan dengan literature dari SNI 1869 -2008 tentang standar pelek kendaraan bermotor, serta mempergunakan simulasi system software komputansi SOLID WORK 2017. Pada proses SOLID WORK dilakukan dengan simulasi static, torsi, dan FEA (Finite Element Analysis). Pelek yang dilakukan pada analisis terdiri dari tipe 1, 2, dan 3. Hasil yang diperoleh dari analisa perhitungan dan pengujian secara matematis adalah hampir mendekati dari system analisis komputansi. Dari beberapa pelek yang telah dilakukan pengujian secara soft ware SOLID WORK 2017, penulis memperoleh hasil pelek 2, yang lebih unggul dari tipe 1 dan 3. Keunggulan pelek tipe berupa nilai displacement sebesar 8.576e-3 mm (pada simulasi static), Von Mises Stress sebesar 9.629e+7 N/m2, displacement sebesar $2.189 \mathrm{e}-1 \mathrm{~mm}$, strain sebesar 8.832e-4 (pada simulasi torsi), dan displacement sebesar $2.311 \mathrm{e}-2 \mathrm{~mm}$ (pada simulasi FEA).
\end{abstract}

Kata Kunci: Alloy, Aluminium FEA, Pelek, Strain, Stress

ABSTRACT

The rim is a vehicle unit that functions as a retaining / supporting vehicle load when it is stationary, and as a successor to the rotary motion of the engine to move the vehicle from one place to another. This vehicle rim is for 4-wheeled vehicles with the main raw material being aluminum and combined with other materials (alloys) with a 1060 aluminum alloy alloy.

In this rim through several stages of the testing process to determine the strength when static and dynamic.The analysis process with a calculation method that is adjusted to the literature of SNI 1869-2008 on motorized rim standards, and uses SOLID WORK 2017. The SOLID WORK process is done by static simulation, torque, and FEA (Finite Element Analysis). The rims carried out in the analysis consist of types 1, 2, and 3.

The results obtained from the analysis of calculations and mathematical testing are almost close to the computational analysis system. From several rims that have been tested by SOLID WORK 2017 soft ware, the authors obtained rim results 2 , which are superior to type 1 and 3 . The advantages of type rims are displacement values of $8.576 \mathrm{e}-3 \mathrm{~mm}$ (in static simulation), Von Mises Stress amounting to $9.629 \mathrm{e}+7 \mathrm{~N} / \mathrm{m} 2$, displacement of $2.189 e-1 \mathrm{~mm}$, strain of $8.832 \mathrm{e}-4$ (in torque simulation), and displacement of $2.311 \mathrm{e}-2 \mathrm{~mm}$ (in FEA simulation).

Keywords $\quad$ : Alloy, Aluminum, FEA, Rim, Strain, Stress,

\section{PENDAHULUAN}

Pelek atau Velg merupakan salah satu komponen otomotif yang terus mengalami kemajuan desain, dan terlebih lagi banyak mengutamakan estetikanya. Oleh karenanya dibutuhkan desain baru dari sebuah pelek yang dapat memenuhi keinginan para konsumen. Namun perlu kita perhatikan bahwa desainnya haruslah memenuhi kriteria pengujian. Sebuah pelek, layak untuk diproduksi apabila telah memenuhi tahapan pengujian.
Jumlah permintaan pelek di Indonesia terus meningkat, baik modifikasi pelek maupun kebutuhan suku cadang standar kendaraan merek tertentu. Salah satu masalah yang terjadi adalah variasi pelek modifikasi yang sangat beragam yang tentu saja harus di standarisasi demi keamanan dan kenyamanan pengendara. Pelek merupakan komponen penting yang mentransmisikan daya dari kendaraan ke roda. Jenis pembebanan dapat berupa beban statis maupun beban dinamis. Adapun beban dinamis sudah di standarisasi oleh Badan Standarisasi Nasional (BSN). 
Standar Nasional Indonesia (SNI) mengatur standarisasi pelek kendaraan. Pelek yang memenuhi standar SNI harus memiliki logo SNI di dalamnya yang mengindikasikan produk ini sudah lulus uji SNI. Standar pelek kendaraan ber motor diatur dalam SNI 1896:2008 yang mengacu pada JASO C 614-87 Disc Wheel for Automobile, JIS D 4103-1998 Disc Wheel for Automobile, dalam beberapa syarat mutu dan kualitas[1]. Beberapa persyaratan mutu untuk pelek kendaraan bermotor roda empat dapat diklasifikasikan dengan katagori $\mathrm{M}, \mathrm{N}, \mathrm{O}$, L. Pelek paduan logam ringan yang diproses secara rolling, mempergunakan pengujian beban radial dinamis dan pengukuran deefleksi pelek[2].

Salah satu metode yang sudah banyak digunakan untuk menganalisa karakteristik pelek adalah metode elemen hingga, Finite Element Method (FEM) atau Finite Element Analysis (FEA). Metode FEA dapat menyelesaikan masalah struktur kompleks pada mekanika benda padat untuk menghasilkan solusi berupa tegangan, regangan, defleksi hingga umur fatigue. Keunggulan dari metode FEA adalah penggunaan waktu dan biaya yang minimum, bahkan metode ini dapat digunakan sebelum prototype yang sebenarnya dibuat, disamping itu metode ini juga telah didukung oleh perangkat lunak berbasis CAE seperti program Solidworks dan program Pro Engineering.

Memformulasikan model finite element pada roda sepeda klasik dan membandingkan hasilnya dengan Pro Engineering untuk parameter displacement, strain dan bending pada roda tersebut. Hasilnya menunjukkan bahwa permodelan menggunakan Pro Engineering dapat menjadi alat yang sangat berguna untuk menganalisa struktur sederhana seperti roda sepeda[3].

Mengajukan sebuah metode baru untuk menganalisa umur fatigue menggunakan FEA program ABAQUS untuk permodelan finite element beban statis. Hasilnya mengindikasikan penggabungan antara metode FEA dengan nominal stress adalah cara yang baik dan efisien untuk memperkirakan umur fatigue roda aluminium[4].

Menganalisa pelek sebuah mobil dengan test pembebanan 400 menggunakan FEA dan membandingkan hasilnya dengan hasil ekspepeleken. Penelitian serupa juga dilakukan Sunil N. Yadav dan N.S. Hamamapure (2013) yang menganalisa mobil penumpang dengan pembebanan pelek secara radial pada lapangan off road untuk menghitung umur fatigue pelek[5].
Penelitian sebelumnya menemukan bahwa estimasi umur pelek aluminium alloy menghasilkan over design dari produk (misalkan umur yang diharapkan adalah $300.000 \mathrm{~km}$ sedangkan umur yang terhitung hingga $25.200 .000 \mathrm{~km}$ ). Beberapa hal perlu dilakukan untuk medesain ulang daerahdaerah yang kritis dari pelek, seperti spoke. Hal ini dapat menghasilkan pengurangan penggunaan material dalam proses pengecoran logam yang mana menurunkan biaya produksi tanpa memberikan kompromi pada kehandalan produk selama usia pakainya[6].

\section{METODE PENELITIAN}

Perkembangan teknologi di dalam dunia otomotif untuk memberikan rasa aman serta nyaman dalam proses berkendaraan adalah penggunaan pelek yang ringan, dapat menahan beban yang cukup tinggi, dan memiliki nilai tambah dalam penampilan. Untuk proses secara cepat, teliti dan efesien, maka desain pelek mobil dapat dilakukan dengan menggunakan simulasi sistem software[7]. Mendesain pelek dengan secara manual sudah tidak dipergunakan lagi, maka soft ware merupakan kelanjutan untuk membuat desain secara efektif dan efesien. Software yang telah digunakan untuk simulasi pelek pada kendaraan roda dua adalah Autodesk Invertor, dimana dapat membuat jenis pelek, kekuatan bahan yang dipergunakan, mengetahui beban statis dan dimanis dari pengujian, serta dapat mengetahui faktor keamanan lebih dari 1.0[8]. Desain pelek dengan menggunakan software untuk membuat spok dari 10, 12, 14 dapat dipergunakan pemodelan menggunakan AutoCAD, serta dapat disimulasikan menggunakan software Solidwork 2017 yang berbasis Finite Element Method (FEM), dimana dapat mengetahui beban yang terjadi, kekuatan, titik kritis, tegangan maksimum, serta deformasi maksimum yang terjadi[9].

Dalam proses analisis kekuatan pelek mobil, oleh karena itu kerangka penelitian seperti digambarkan pada gambar.1 dibawah ini: 


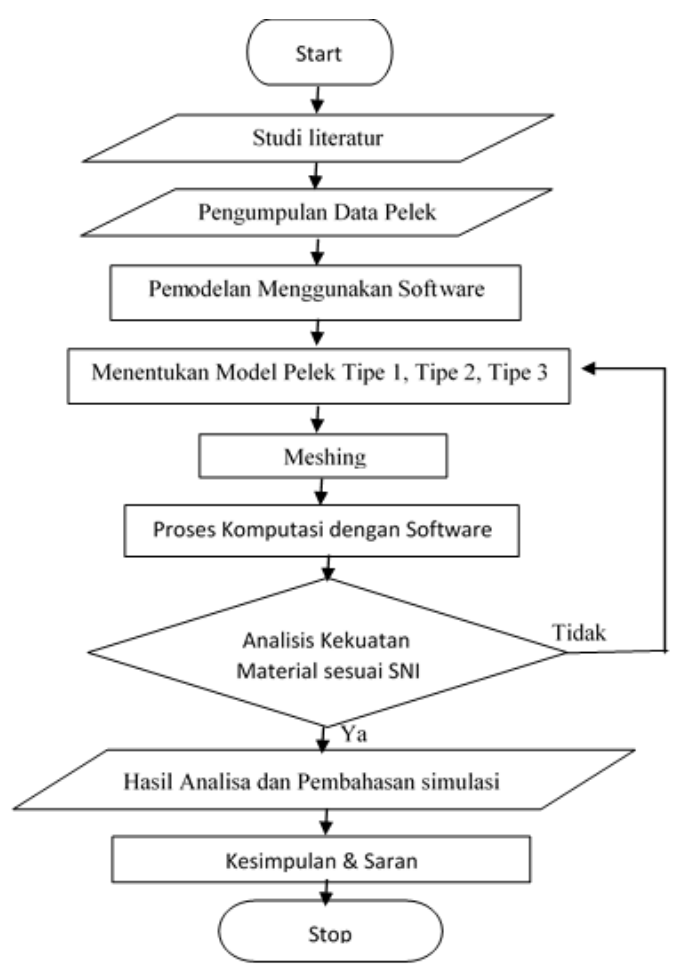

Gambar 1. Kerangka Penelitian

Penentuan tipe yang dilakukan untuk menjadi desain dan produk adalah kesesuaian antara bahan material yang dipergunakan, model, proses kerja yang dilakukan, serta ketahanan material produk jadi. Dalam hal ini untuk melakukan proses langsung menjadi produk jadi tanpa mengetahui kekuatan/ketangguhan material produk akan sangat beresiko untuk produk dan profil. Untuk menghidari hal tersebut dilakukan desain menggunakan software yang valid dan dapat dipergunakan untuk mengetahuinya. Penelitianini melakukan desain dengan software Solid Work 2017, karena lebih mudah, efektif, dan efesien. Optimasi yang dilakukan penulis adalah melakukan desain dengan berbagai model/tipe pada pelek 17 inci, melakukan desain, meshing, pemberian beban statik dan dinamik pada pelek. Di dalam proses manual tidak ada, sehingga tidak dapat diperoleh nilai kekerasan, titik kritis, serta pembebanan maksimal di setiap bagian (node).

\section{HASIL DAN PEMBAHASAN}

Langkahutama didalam penelitian ini adalah pertama-tama mengidentifikasi masalah yang akan di teliti kemudian mengkaji masalah tersebut secara lebih mendalam dengan melakukan studi literatur. Setelah ditentukan permasalahan berupa membandingkan konfigurasi pelek dan parameter yang akan dijadikan kajian, maka dipilih metode FEA untuk mengumpulkan data-datanya. Adapun berikut ini dijelaskan rincian dari langkah-langkah metode FEA. Desain model geometri dilakukan menggunakan software CAD Solidwork dandi analisis dengan Solidwork. Dimensi pelek 17inch (431.8 $\mathrm{mm})$ dengan lebar 8.5 inch $(215.9 \mathrm{~mm})$ model terdiri dari tiga variasi, seperti digambarkan pada gambar.2, gambar.3, dan gambar.4 dibawah ini.

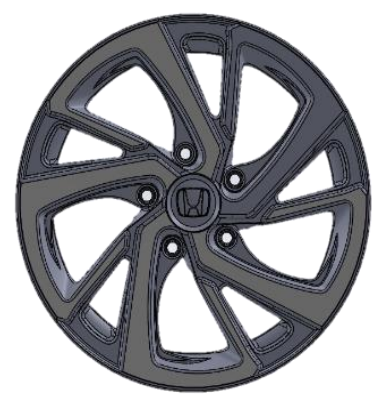

Gambar 2. Pelek Tipe 1

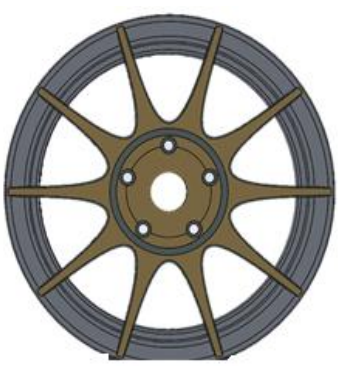

Gambar 3. Pelek Tipe 2

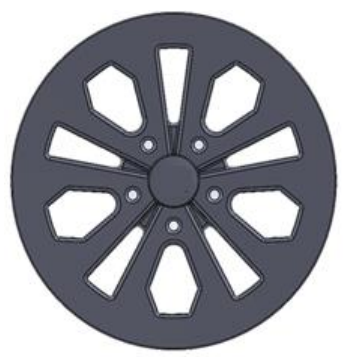

Gambar 4. Pelek Tipe 3

Meshing atau griding adalah merubah model kontinyu menjadi model disktrit agar bisa diselesaikan solusinya secara numerik. Meshing dilakukan menggunakan salah satu fitur yang ada pada software SOLID WORK 2017. Pengaturan yang digunakan dalam meshing adalah merubah relevance centre menjadi "medium" dan merubah ukuran keseluruhan elemen menjadi ukuran $2 \mathrm{~mm}$ untuk mendapatkan hasil perhitungan yang akurat serta kontur yang halus, seperti ditampilkan pada gambar.5, gambar.6, dan gambar.7 dibawah ini. 


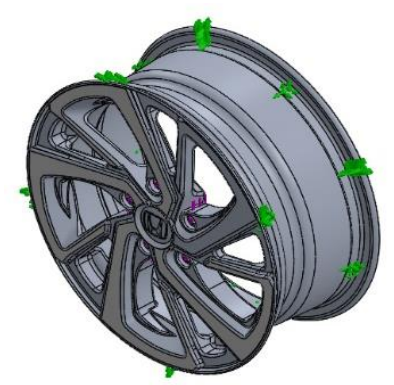

Gambar 5. Meshing Pelek Tipe 1

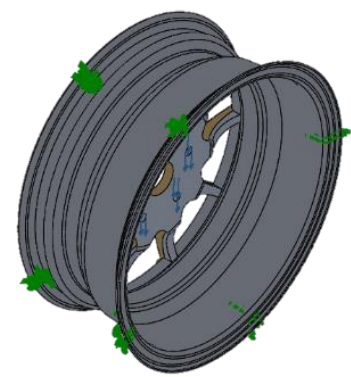

Gambar 6. Meshing Pelek Tipe 2

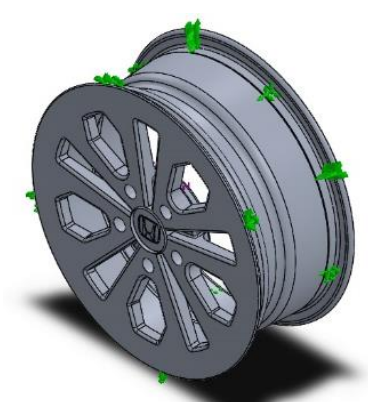

Gambar 7. Meshing Pelek Tipe 3

Pada pelek tipe 3, dilihat massa, volume, dan berat adalah lebih besar dibandingkan dengan tipe 1, 2. Adapun tabel perbandingan karakteristik secara static dapat dilihat pada tabel di bawah ini.

Tabel 1. Perbandingan Karakteristik pada Pelek Tipe 1, 2, dan 3 .

\begin{tabular}{|c|c|c|c|}
\hline Item & Tipe 1 & Tipe 2 & Tipe 3 \\
\hline Massa $(\mathrm{kg})$ & 13.0043 & 9.23233 & 14.856 \\
\hline Volume $(\mathrm{m} 3)$ & 0.00481641 & 0.00341939 & 0.00550223 \\
\hline $\begin{array}{c}\text { Massa Jenis } \\
(\mathrm{kg} / \mathrm{m} 3)\end{array}$ & 2700 & 2700 & 2700 \\
\hline Berat $(\mathrm{N})$ & 127.442 & 90.4769 & 145.589 \\
\hline
\end{tabular}

Sumber : data olahan 2018

Dengan mempergunakan softwaresimulasi SOLID WORK 2017, data yang dapat ditampilkan untuk pelek tipe 1,2, dan 3 untuk static pelek seperti dijelaskan pada Tabel.2 dibawah ini adalah sebagai berikut:
Tabel 2. Statik Pelek.

\begin{tabular}{|l|c|c|c|}
\hline \multicolumn{1}{|c|}{ Item } & Tipe 1 & Tipe 2 & Tipe 3 \\
\hline Name & 1060 Alloy & 1060 Alloy & 1060 Alloy \\
\hline Model type & $\begin{array}{c}\text { Linear Elastic } \\
\text { Isotropic }\end{array}$ & $\begin{array}{c}\text { Linear Elastic } \\
\text { Isotropic }\end{array}$ & $\begin{array}{c}\text { Linear Elastic } \\
\text { Isotropic }\end{array}$ \\
\hline $\begin{array}{l}\text { Default failure } \\
\text { criterion }\end{array}$ & Unknown & Unknown & Unknown \\
\hline \multicolumn{1}{|c|}{ Item } & Tipe 1 & Tipe 2 & Tipe 3 \\
\hline Yield strength & $\begin{array}{c}2.75742 \mathrm{e}+007 \\
\mathrm{~N} / \mathrm{m}^{\wedge} 2\end{array}$ & $\begin{array}{c}2.75742 \mathrm{e}+007 \\
\mathrm{~N} / \mathrm{m}^{\wedge} 2\end{array}$ & $\begin{array}{c}2.75742 \mathrm{e}+007 \\
\mathrm{~N} / \mathrm{m}^{\wedge} 2\end{array}$ \\
\hline Tensile strength & $\begin{array}{c}6.89356 \mathrm{e}+007 \\
\mathrm{~N} / \mathrm{m}^{\wedge} 2\end{array}$ & $\begin{array}{c}6.89356 \mathrm{e}+007 \\
\mathrm{~N} / \mathrm{m}^{\wedge} 2\end{array}$ & $\begin{array}{c}6.89356 \mathrm{e}+007 \\
\mathrm{~N} / \mathrm{m}^{\wedge} 2\end{array}$ \\
\hline Elastic modulus & $6.9 \mathrm{e}+010 \mathrm{~N} / \mathrm{m}^{\wedge} 2$ & $6.9 \mathrm{e}+010 \mathrm{~N} / \mathrm{m}^{\wedge} 2$ & $6.9 \mathrm{e}+010 \mathrm{~N} / \mathrm{m}^{\wedge} 2$ \\
\hline Poisson's ratio & 0.33 & 0.33 & 0.33 \\
\hline Mass density & $2700 \mathrm{~kg} / \mathrm{m}^{\wedge} 3$ & $2700 \mathrm{~kg} / \mathrm{m}^{\wedge} 3$ & $2700 \mathrm{~kg} / \mathrm{m}^{\wedge} 3$ \\
\hline Shear modulus & $2.7 \mathrm{e}+010 \mathrm{~N} / \mathrm{m}^{\wedge} 2$ & $2.7 \mathrm{e}+010 \mathrm{~N} / \mathrm{m}^{\wedge} 2$ & $2.7 \mathrm{e}+010 \mathrm{~N} / \mathrm{m}^{\wedge} 2$ \\
\hline $\begin{array}{l}\text { Thermal } \\
\text { expansion } \\
\text { coefficient }\end{array}$ & $\begin{array}{l}\mid r 4 \mathrm{e}-005 / \mathrm{Kelvin} \\
2.4 \mathrm{e}-005 / \mathrm{Kelvin}\end{array}$ & $2.4 \mathrm{e}-005 / \mathrm{Kelvin}$ \\
\hline \multicolumn{4}{|c|}{ Sumber : data olahan 2018} \\
\hline
\end{tabular}

Dengan menggunakan metode Von Miss Stress (VON) pada pelek tipe 1, maka dapat diperoleh titik kritis pada bagian yang mengalami pembebanan secara statis. Gaya yang terjadi pada pelek tipe 1 terdapat gaya minimum sebesar $4.818 \mathrm{e}-$ $2 \mathrm{~N} / \mathrm{m} 2$, dan maksimum sebesar 8.247e+6

$\mathrm{N} / \mathrm{m} 2$. Pada pelek tipe 1 terjadi tegangan luluh (yield strength sebesar $2.757 \mathrm{e}+7 \mathrm{~N} / \mathrm{m} 2$, seperti dilihat pada gambar.8 di bawah ini.

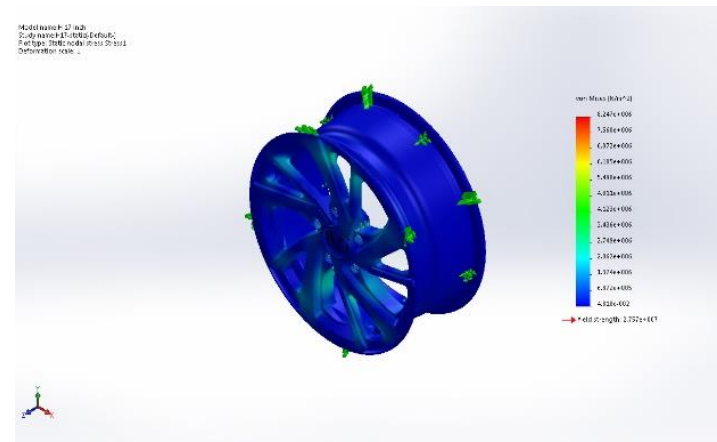

Gambar 8. Von Miss Stress Pelek Tipe 1

Pada pelek tipe 2, diperoleh Von Mises Stress minimum sebesar $2.035 \mathrm{e}-002 \mathrm{~N} / \mathrm{m} 2$ pada titik 25122, dan maksimum sebesar $5.164 \mathrm{e}+006 \mathrm{~N} / \mathrm{m} 2$ pada titik 7336. Seperti dilihat pada gambar.9 di bawah ini.
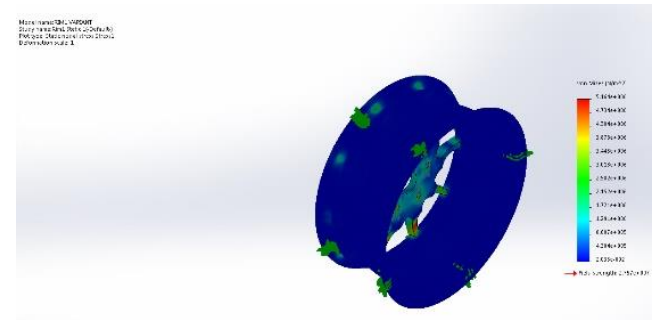

L

Gambar 9. Von Miss Stress Pelek Tipe 2

Pada pelek tipe 3, dengan menggunakan Von Mises Stress, dimana minimum diperoleh dengan angka 5.084e-002 N/m2 pada titik 36890 dan 
maksimum stress adalah sebesar $6.033 \mathrm{e}+006 \mathrm{~N} / \mathrm{m} 2$ pada titil 22491. Seperti dilihat pada gambar.10 di bawah ini.

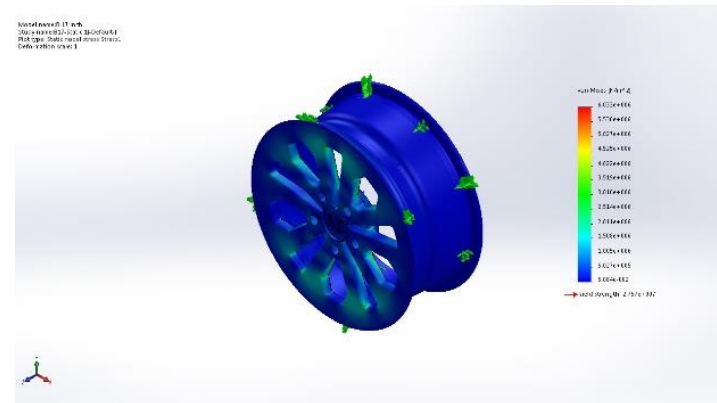

Gambar 10. Von Miss Stress Pelek Tipe 3

Dengan mengetahui Von Mises Stress yang terjadi pada pelek tipe 1, 2, 3 maka dapat dibuatkan tabel seperti yang ditampilkan padatabel.3.Pada tabel.3 diperoleh bahwa Von Mises Stress maksimum terdapat pada pelek tipe 1 sebesar $8.247 \mathrm{e}+006 \mathrm{~N} / \mathrm{m}^{2}$.

Tahel 3. Von Miss Stress Pelek

\begin{tabular}{|c|l|c|c|}
\hline Name & \multicolumn{1}{|c|}{ Type } & Min & Max \\
\hline Stress Tipe 1 & VON: von Mises Stress & $\begin{array}{c}4.818 \mathrm{e}-002 \mathrm{~N} / \mathrm{m}^{\wedge} 2 \\
\text { Node: } 118270\end{array}$ & $\begin{array}{c}8.247 \mathrm{e}+006 \mathrm{~N} / \mathrm{m}^{\wedge} 2 \\
\text { Node: } 41595\end{array}$ \\
\hline Stress Tipe 2 & VON: von Mises Stress & $\begin{array}{c}2.035 \mathrm{e}-002 \mathrm{~N} / \mathrm{m}^{\wedge} 2 \\
\text { Node: } 25122\end{array}$ & $\begin{array}{c}5.164 \mathrm{e}+006 \mathrm{~N} / \mathrm{m}^{\wedge} 2 \\
\text { Node: } 7336\end{array}$ \\
\hline Stress Tipe 3 & VON: von Mises Stress & $\begin{array}{c}5.084 \mathrm{e}-002 \mathrm{~N} / \mathrm{m}^{\wedge} 2 \\
\text { Node: } 36890\end{array}$ & $\begin{array}{c}6.033 \mathrm{e}+006 \mathrm{~N} / \mathrm{m}^{\wedge} 2 \\
\text { Node: } 22491\end{array}$ \\
\hline
\end{tabular}

Perubahan torsi yang terjadi pada pelek tipe 1, dengan pemberian nilai perubahan sebesar minimum $0.00 \mathrm{e}+0 \mathrm{~mm}$ pada titik 91 dan maksimum sebesar 3.908e-002mm pada titik 2943, maka terjadi perubahan torsi pada pelek tipe 1 tersebut. Perubahan tersebut dalam bentuk warna biru, hijau, kuning, dan merah. Seperti yang ditampilkan pada gambar.11 dibawah ini.

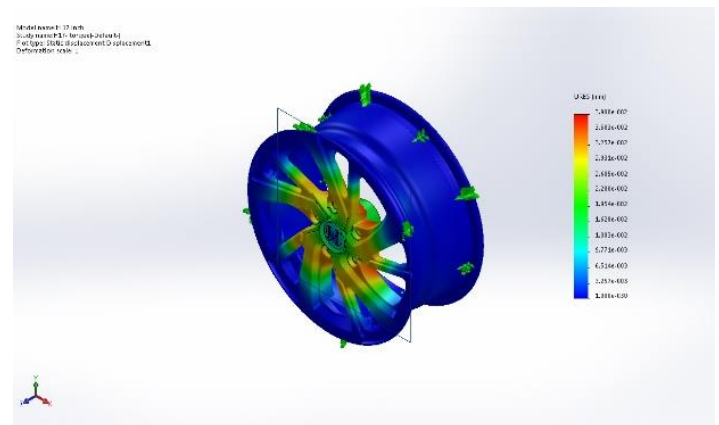

Gambar 11. Perubahan Torsi Pelek Tipe 1

Perubahan torsi dimulai dari biru menuju merah, dimana angka biru sebesar $1.0 \mathrm{e}-030 \mathrm{~mm}$, sedangkan yang berwarna merah sebesar 3.908e$002 \mathrm{~mm}$. perubahan besar torsi akan mempengaruhi warna. Dengan torsi yang kecil, maka warna akan menjadi biru (kondisi aman), sedangkan pemberian torsi yang besar pada pelek tipe 1, maka akan berubah menjadi berwarna kunig (kondisi perhatian), dan memasuki warna merah, maka pelek tipe 1 dalam kondisi yang kritis, sehingga akan terjadi kerusakan/patah. Oleh sebab itu, perlu diperhatikan untuk menjaga pelek tipe 1 tidak dalam daerah berwarna merah, sehingga tidak terjadi kerusakan.

Pada tabel.4 dibawah ini,menunjukkan harga displacement pada pelek yang paling besar adalah pada tipe 2, sebesar $2.189 \mathrm{e}-001 \mathrm{~mm}$ pada titik 43470.

Tabel 4. Displacement Pelek

\begin{tabular}{|c|c|c|c|}
\hline Name & Type & Min & Max \\
\hline Displacement Tipe 1 & $\begin{array}{c}\text { URES: Resultant } \\
\text { Displacement }\end{array}$ & $\begin{array}{c}0.000 \mathrm{e}+000 \mathrm{~mm} \\
\text { Node: } 91\end{array}$ & $\begin{array}{c}3.908 \mathrm{e}-002 \mathrm{~mm} \\
\text { Node: } 2943\end{array}$ \\
\hline Displacement Tipe 2 & $\begin{array}{c}\text { URES: Resultant } \\
\text { Displacement }\end{array}$ & $\begin{array}{c}0.000 \mathrm{e}+000 \mathrm{~mm} \\
\text { Node: } 8\end{array}$ & $\begin{array}{c}2.189 \mathrm{e}-001 \mathrm{~mm} \\
\text { Node: } 43470\end{array}$ \\
\hline Displacement Tipe 3 & $\begin{array}{c}\text { URES: Resultant } \\
\text { Displacement }\end{array}$ & $\begin{array}{c}0.000 \mathrm{e}+000 \mathrm{~mm} \\
\text { Node: } 1172\end{array}$ & $\begin{array}{c}5.253 \mathrm{e}-002 \mathrm{~mm} \\
\text { Node: } 25473\end{array}$ \\
\hline
\end{tabular}

Sumber : data olahan 2018

Pada kondisi pelek tipe 1 dilakukan peregangan, terlihat bahwa kondisi pelek dalam kondisi aman (berwarna biru dan hijau). Pada penelitian ini memmberikan nilai minimum sebesar 3.640e-012 pada titik 22893 dan maksimum sebesar 7.165e-004 pada titik 16457, seperti terlihat pada gambar.12 di bawah ini.

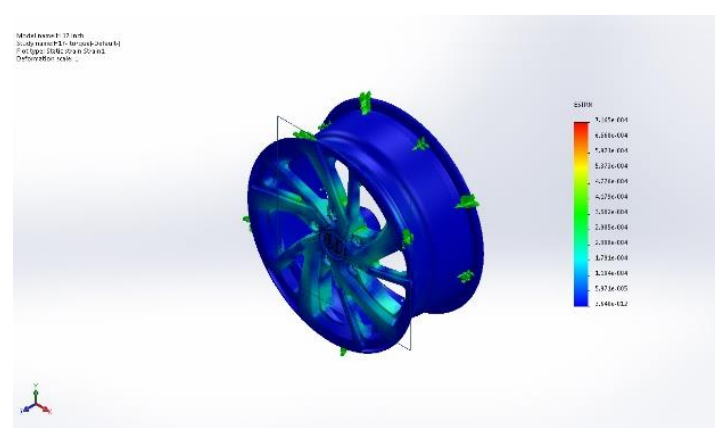

Gambar 12. Peregangan Torsi Pelek Tipe 1

Pada tabel.5 di bawah ini, menunjukkan nilai minimum dan maksimum strain torsi beberapa tipe pelek.Pada data tabel tersebutmenunjukkan harga regangan besar berada pada pelek tipe 2, yaitu sebesar 8.832e-004 pada elemen 26648.

Tabel 5. Strain Torsi Pelek

\begin{tabular}{|c|c|c|c|}
\hline Name & Type & Min & Max \\
\hline Strain Tipe 1 & ESTRN: Equivalent Strain & $\begin{array}{c}3.640 \mathrm{e}-012 \\
\text { Element: } 22893\end{array}$ & $\begin{array}{c}7.165 \mathrm{e}-004 \\
\text { Element: } 16457\end{array}$ \\
\hline Strain Tipe 2 & ESTRN: Equivalent Strain & $\begin{array}{c}8.941 \mathrm{e}-013 \\
\text { Element: } 33346\end{array}$ & $\begin{array}{c}8.832 \mathrm{e}-004 \\
\text { Element: } 26648\end{array}$ \\
\hline Strain Tipe 3 & ESTRN: Equivalent Strain & $\begin{array}{c}1.564 \mathrm{e}-012 \\
\text { Element: } 16249\end{array}$ & $\begin{array}{c}6.173 \mathrm{e}-004 \\
\text { Element: } 24948\end{array}$ \\
\hline
\end{tabular}

Sumber : data olahan 2018

Berdasarkan data-data yang telah diperoleh dari simulasi software SOLID WORK 2017 pada 
pelek tipe 1, 2, dan 3 maka dapat dibuat tabel ringkasan hasil maksimum dari simulasi proses statis, simulasi proses torsi, dan simulasi proses FEA (Finite Element Analysis), seperti ditampilkan pada tabel.6 di bawah ini.

Tabel 6. Perbandingan Hasil Simulasi 3 Tipe Pelek.

\begin{tabular}{|c|l|c|c|c|}
\hline \multirow{2}{*}{ No } & \multirow{2}{*}{ Item } & \multicolumn{3}{|c|}{ Simulasi } \\
\cline { 3 - 5 } & \multirow{2}{*}{1} & Statik & Torsi & FEA \\
\hline \multirow{2}{*}{2} & $\begin{array}{l}\text { Rosultan Gaya } \\
\text { Stress }\end{array}$ & $\begin{array}{c}\text { Tipe } 3 \\
(5800 \mathrm{~N})\end{array}$ & $\begin{array}{c}\text { Tipe } 1 \\
(840.957 \mathrm{~N})\end{array}$ & $\begin{array}{c}\text { Tipe } 3 \\
(404.025 \mathrm{~N})\end{array}$ \\
\hline \multirow{2}{*}{3} & Displacement & $\begin{array}{c}\text { Tipe } 1 \\
(8.247 \mathrm{e}+6 \mathrm{~N} / \mathrm{m} 2)\end{array}$ & $\begin{array}{c}\text { Tipe 2 } \\
(9.629 \mathrm{e}+7 \mathrm{~N} / \mathrm{m} 2)\end{array}$ & $\begin{array}{c}\text { Tipe3 } \\
(1.542 \mathrm{e}+7 \mathrm{~N} / \mathrm{m} 2)\end{array}$ \\
\hline \multirow{2}{*}{4} & Strain 2 & $\begin{array}{c}\text { Tipe 2 } \\
(8.576 \mathrm{e}-3 \mathrm{~mm})\end{array}$ & $\begin{array}{c}\text { Tipe } 2 \\
(2.311 \mathrm{e}-2 \mathrm{~mm}-1 \mathrm{~mm})\end{array}$ \\
\hline
\end{tabular}

Sumber : data olahan 2018

Dengan melihat dan menganalisa dari hasil tabel.6 di atas,dan mengamati beberapa variable simulasi yang dilakukan dengan cara static, torsi, dan FEA. Pada simulasi static, pelek tipe1 memiliki keunggulan dibidang Von Mises Stress dan Strain, sedangkan tipe 2 memiliki keunggulan dibidang displacement, serta tipe 3 dari segi resultan gaya static. Pada simulasi torsi, pelek tipe 2 memiliki keunggulan dari bidang Von Mises Stress, displacement, dan Strain, sedangkan tipe 1 hanya resultan gaya. Untuk simulasi dibidang FEA, pelek tipe 3 memiliki keunggulan dibidang resultan gaya, dan Von Mises Stress. Sedangkan tipe 2 dan 1 memiliki keunggulan dibidang displacement dan strain saja. Dengan demikian, pelek tipe 2 memiliki keunggulan dan kelebihan yang lebih banyak dibandingkan dengan tipe 1 dan 3. Dimana pelek tipe 2 memiliki keunggulan berupa nilai displacement (pada simulasi static), Von Mises Stress, displacement, strain (pada simulasi torsi), dan displacement (pada simulasi FEA).

\section{KESIMPULAN}

Dari penelitian yang dilakukan terdapat beberapa kesimpulan yang dapat diambil yaitu: Pelek tipe 2 memiliki keunggulan pelek tipe berupa nilai displacement sebesar $8.576 \mathrm{e}-3 \mathrm{~mm}$ (pada simulasi static), Von Mises Stress sebesar 9.629e+7 N/m2, displacement sebesar $2.189 \mathrm{e}-1 \mathrm{~mm}$, strain sebesar 8.832e-4 (pada simulasi torsi), dan displacement sebesar 2.311e-2 mm (pada simulasi FEA). Perhitungan yang diisyaratkan oleh standar SNI dengan cara manual masih di bawah ambang isyarat yang telah ditentukan oleh SNI 1896 : 2008 (nilai gaya tekan pada pelek sebesar $5800 \mathrm{~N}$ adalah sama dengan simulasi FEA Solid Work 2017, nilai kecepatan yang dihasilkan adalah $115.79 \mathrm{rad} / \mathrm{s}$ adalah sama dengan simulasi
FEA Solid Work 2017, serta tegangan yang terjadi 18.3 MPa untuk FEA Solid Work 2017 adalah 96.29 $\mathrm{MPa}$, regangan yang terjadi adalah 0.00255 untuk FEA Solid Work 2017 adalah 0.0008832. secara umum FEA dapat dijadikan sebagai sistem komputansi dengan software Solid Work 2017 yang dapat menilai secara cepat dan dapat mengetahui/menjawab standar SNI 1896:2008 yang telah diisyaratkan.

Dengan memperhatikan hasil desain variasi pelek yang dilakukan menngunakan software SOLID WORK 2017, maka tipe yang optimal adalah tipe 2 . Pelek tipe memiliki keunggulan yaitu kekuatan menahan tegangan/stress dari beban berputar (torsi $9.63 \mathrm{E}+07 \mathrm{~N} / \mathrm{m}^{2}$ ), dapat menahan pergeseran (displacement 2.19E-01 $\mathrm{mm}$ ), serta memiliki nilai peregangan (strain 8.83E-04).

\section{DAFTAR PUSTAKA}

[1] M. N. Akbar, "Simulasi Pengujian Impact Drop-Test Berdasarkan Standarisasi SNI dan Analisa Perubahan Deain Rim Mobil Penumpang Dengan Metode Elemen Hingga.," Institut Teknologi Sepuluh November, Surabaya, 2017.

[2] SNI 1896:2008, "Pelek Kendaraan Bermotor Kategori M N dan O," Badan Standarisasi Nasional, Jakarta, 2008.

[3] A. D. Hartz, Finite Element Analysis of The Classic BicycleWheel, Indiana: Raytheon Eng. Prod. Support Indianap, 2002.

[4] L. Wang, Y. Chen, W. C and W. Q, "Fatique Life Analysis of Aluminum Wheels by Simulation of Rotary Fatique Test," Stroj. Vestnik/Journal Mech. Eng., vol. 57, no. 1, pp. 31-39, 2011.

[5] A. V. R. Sorin, I. R. C and Et.al, "Mechanical Testing Methods Concerning The Stress Analysis for a Vehicle Wheel Rim," vol. 2, pp. 33-39.

[6] M. D. Mary, The Design of an Aluminium Alloy Wheel Using Three Dimensional Finite Element Analysis and Fatique Life Prediction, Dublin: Dublin City University, 1996.

[7] L. P. D. Prameswari, Pengembangan Aplikasi Simulasi Mesin Mobil Berbasis Multimedia, Yogyakarta: Universitas Atma Jaya Yogyakarta, 2009.

[8] E. A. Syaefudin and I. Basori, "Perancangan Desain Velg Sepeda Motor Hybrid dan Pengujian Distribusi Beban Dengan Software Autodesk Invertor," Jurnal Konversi Energi dan Manufaktur UNJ, vol. Oktober 2013, no. Edisi 1, 2013. 
[9] H. R. Dalimunthe, Desain dan Analisis Velg Mobil Berbasis Aluminium Alloy, Medan: Universitas Sumatera Utara, 2014. 